\title{
Phoretic mites identified on andean hummingbirds (Trochilidae) of Caldas, Colombia
}

\author{
Ácaros foréticos em beija-flores dos Andes (Trochilidae) de Caldas, Colômbia \\ Natalia López-Orozco ${ }^{1}$; William Alberto Cañón-Franco ${ }^{2 *}$
}

\begin{abstract}
${ }^{1}$ Departamento de Parasitologia, Instituto de Ciências Biomédicas, Universidade de São Paulo - USP, São Paulo, SP, Brasil
${ }^{2}$ Laboratorio de Parasitología Veterinaria, Departamento de Salud Animal, Facultad de Ciencias Agropecuarias,

Universidad de Caldas, Manizales, Colombia
\end{abstract}

Received March 10, 2012

Accepted February 14, 2013

\begin{abstract}
Within the bird-plant-mite system, the relationship between hummingbirds, flowers, and mites remains poorly understood. In this study, we evaluated the degree of association between nasal mites and eight species of Andean hummingbirds in Colombia (Amazilia saucerrottei, A. tzacatl, Chalybura buffonii, Chlorostilbon mellisugus, Florisuga mellivora, Glaucis hirsutus, Phaethornis guy and P. striigularis). Over a five-month period (trapping effort 360 hours/month), a total of 178 birds were captured, from which 81 mite specimens were collected and identified as belonging to three genera (Proctolaelaps, Rhinoseius and Tropicoseius) spanning eleven species. This is the first report of its kind from Colombia on the identification of the mite species P. rabulatus, R. luteyni, R. rafinskii, T. berryi, T. colwelli, T. erro and T. uniformis and the first record of $P$. guy as phoretic host for Proctolaelaps rabulatus. Morphological characteristics (length of the dorsal plate, width of the dorsal plate and setae z5 length) alone failed to distinguish between mite species. The ecologic impact of this relationship on flowers with respect to nectar and pollen availability and the effect of mites on pollination by hummingbirds needs to be determined.
\end{abstract}

Keywords: Hummingbirds, Tropicoseius, nasal mites, flower mites, phoresia.

\section{Resumo}

Pouco conhecido, o termo "ácaros de flores de beija-flor" define as relaçóes entre o sistema ave-planta-ácaro. Nesta pesquisa foi avaliado o grau de associação entre ácaros foréticos nasais e oito espécies de beija-flores dos Andes colombianos (Amazilia saucerrottei, A. tzacatl, Chalybura buffonii, Chlorostilbon mellisugus, Florisuga mellivora, Glaucis hirsutus, Phaethornis guy, P. striigularis). Um total de 178 beija-flores foram capturados durante cinco meses (esforço de captura 360 horas/mês) no qual 81 espécimes de ácaros foram coletados e identificados em três gêneros (Proctolaelaps, Rhinoseius e Tropicoseius) e onze espécies. Este é o primeiro registro para Colômbia das espécies P. rabulatus, R. luteyni, R. rafinskii, T. berryi, T. colwelli, T. erro e T. uniformis, e o primeiro registro de P. guy como hospedeiro forético para Proctolaelaps rabulatus. Adicionalmente, foram avaliados os caracteres morfológicos (comprimento da placa dorsal, largura da placa dorsal e comprimento da seta z5) que náo foram suficientes, para distinguir entre as espécies de ácaros. O impacto ecológico desta relação nas flores, em termos de néctar e pólen, e o efeito na polinização pelos beija-flores necessita ser esclarecida.

Palavras-chave: Beija-flor, Tropicoseius, ácaros nasais, ácaros de flores, forésia.

\section{Introduction}

Mites of the family Ascidae (Order: Mesostigmata) are commonly found on birds, with over 22 genera and 60 species having been identified (NASKRECKI; COLWELL, 1998). This group includes four genera of nasal mites: Lasioseius Berlese 1916, Proctolaelaps Berlese 1923, Rhinoseius Baker and Yunker 1964

*Corresponding author: William Alberto Cañón-Franco

Facultad de Ciencias Agropecuarias, Universidad de Caldas, Calle 65 No 26,

10, Manizales, Caldas, Colombia

e-mail: william.canon@ucaldas.edu.co and Tropicoseius Bayer and Yunker 1964 (O'CONNOR et al., 1991; PROCTOR; OWENS, 2000; DUSBÄBEK et al., 2007).

Nasal mites are dispersed via a mechanism known as phoresis (Greek phore = to take) (PROCTOR; OWENS, 2000), whereby the temporal association between a mite phoronte and a bird appears to suggest a functional relationship (BAKER; YUNKER, 1964; HOFFMANN, 1996). According to MacChioni (2007), there are at least four types of phoreses classified by relation to the surface of the host, state of quiescence, recognition of signals 
to depart an individual host and, in some cases, synchronization with the life cycle of the host. In this relationship, plants act as a transitory habitat, while birds act as a means of transportation and dispersion but not as hosts for their reproduction (HUNTER, 1972; GUERRA et al., 2010).

Mites of the Ascidae family feed on pollen during the nymphal stage and on nectar during the adult stage (HUNTER, 1972). This food preference is considered to be relatively high, impinging on the food supply of nectarivorous birds and the duration of bird overflights and negatively impacting ornithophilous plant propagation (HEYNEMAN et al., 1991; LARA; ORNELAS, 2001; VELÁSQUEZ; ORNELAS, 2010). As a result, the cospecialization of the mite - hummingbird system is a negative interaction in terms of energy for birds (COLWELL, 1995).

The colonization of hummingbirds by nasal mite species has been reported in several Latin American countries (BAKER; YUNKER, 1964; DUSBÄBEK; ČERNÝ, 1970; HUNTER, 1972; FAIN et al., 1977; HYLAND, 1978; COLWELL; NAEEM, 1979; FAIN; HYLAND, 1980; MICHERDZINSKI; LUKOSCHUS, 1980; O'CONNOR et al., 1991; OHMER, 1991; NASKRECKI; COLWELL, 1998; DUSBÄBEK et al., 2007); however, few studies have considered the hummingbird species as a carrier. In this study, we describe the frequency of presentation of nasal mites on hummingbirds in the Andean region of Colombia and evaluate the degree of association between mite and hummingbird species.

\section{Materials and Methods}

This research was performed in a forest plantation located in Chinchiná, Caldas, Colombia, with an extension of 43 hectares along the Central Cordillera of the Colombian Andes $\left(05^{\circ} 03^{\prime}\right.$ $32^{\prime \prime} \mathrm{N}$ and $75^{\circ} 44^{\prime} 07.6 " \mathrm{O}$ ) that is forested with native species (Cupania americana, Cedrela odorata, Aegiphila grandis and Cordia alliodora) at an altitude of 825-1025 m.a.s.l and has an average temperature of $22.5^{\circ} \mathrm{C}$ and an annual rainfall of $2245 \mathrm{~mm}$.

Five samplings were carried out in April, May, July, August, and September of 2006, with June omitted due to logistical problems. The hummingbirds were captured using mist nets $(12 \times 2.5 \times 0.036 \mathrm{~m})$ located 100 meters from the edge of the plantation (capture effort 360 hours/month) that divided the study area into 40 plots. The birds were identified by a unique combination of color bands and classified according to the system developed by Remsen et al. (2013). Before the birds were released, the following capture variables were registered: date; plot; species; age (immature, adult and unknown), sex (male, female, unknown); reproductive variables, including brood patches (absent, loss of feathers, vascularized, wrinkled, moult, unknown) and protuberance (none, small, medium, large, unknown); and morphometric variables, including exposed culmen, total culmen, beak length, beak width and weight as described by the manual for monitoring birds proposed by Ralph et al. (1996).

Nasal mites were collected directly from the nostrils of birds with the aid of a fine brush (000) and were deposited into 70\% ethanol in glass flasks. Mites were maintained in Entellan ${ }^{\circledast}$ following diaphanization via treatment with $10 \% \mathrm{KOH}$ and drying at $30{ }^{\circ} \mathrm{C}$ for 24 hours (HENDERSON, 2001). Morphological characteristics related to gnathosoma, idiosoma and chaetotaxy were examined via optical microscopy at various magnifications (10X, 40X, 100X) and were used for identification according to the keys proposed by O'Connor et al. (1991) and Naskrecki and Colwell (1998). Each specimen was analyzed for 25 chaetotaxic characters. Morphometric changes in dorsal plate length (DPL), dorsal plate width (DPW) and setae $\mathrm{z} 5$ length (z5) were obtained and expressed as mean values ( $\mathrm{mm}$ ) and standard deviation (DS) (SILVA et al., 2009). The material deposited for reference in the laboratory of Veterinary Parasitology at the University of Caldas.

The data were processed in Excel, and the results were subsequently analyzed using the SPSS 19 package for contingency tables and the Pearson correlation test ( $\mathrm{p} 0.05$ and 0.001 ). For the morphometric variables, major components analysis was performed.

\section{Results}

Over the course of five months, 124 captures and 54 recaptures were performed for 178 hummingbirds spanning eight species (Amazilia saucerrottei, A. tzacatl, Chalybura buffonii, Chlorostilbon mellisugus, Florisuga mellivora, Glaucis hirsutus, Phaethornis guy and P. striigularis). Nasal mites were observed in $25.8 \%$ of the captured birds (46/178), as illustrated in Table 1.

The highest proportion of nasal mites (74\%) was observed in July, coinciding with the frequent capture of $A$. saucerrotte $i$ (41.2\%), P. guy (17.7\%) and C. buffonii (14.7\%) hummingbirds (Table 1). This relationship between mite and hummingbird species establishes a generalist dispersion pattern for Rhinoseius rafinskii and Tropicoseius uniformis mites, while specificity for host transporter was observed among Proctolaelaps rabulatus, $R$. luteyni, $R$. richardsoni and $R$. tiptoni (Table 2 ).

The eighty-one nasal mite specimens identified were classified as belonging to three genera: Tropicoseius (55.6\%), Rhinoseius (43.2\%) and Proctolaelaps (1.2\%). $R$. rafinskii was the most abundant species (27/81), followed by T. uniformis (20/81) and T. berryi (14/81) (Table 2.). This study is the first report on the colonization of hummingbirds in Columbia by seven different species of nasal mites: P. rabulatus, $R$. luteyni, $R$. rafinskii, T. berryi, T. colwelli, T. erro and T. uniformis. Additionally, this report presents five cases of hyperphoresy by an unidentified mite that was transported by P. rabulatus, $R$. rafinskii and T. uniformis nasal mites.

Statistical analyses of the variables using the Pearson correlation test demonstrated associations between the presence of mites, plot $(\mathrm{p}=0.05)$ and date of collection $(\mathrm{p}=0.000)$ (Table 3). Mites were most frequently observed during the month of July (34/81). Although the condition of the feathers of the pectoral muscle "brood patches" (a variable of reproductive type) showed a positive association with the presence of mites ( $p=0.016)$, birds lacking brood patches (absent) were more frequently transporters of mites (26/46) than individuals of the same sex and age.

There was no statistical association between bird and mites species, although it was clear that both hummingbirds and nasal mites showed significant differences in their distributions between the plots studied ( $\mathrm{p}=0.026$ and 0.050 ). In the case of birds, A. saucerottei, C. buffoni, $P$. guy and $P$. striigularis were present in most plots, while A. tzacatl, C. mellisugus, F. mellivora and 
Table 1. Number of hummingbirds captured each month during april - september 2006 in Colombia. The number of hummingbirds with nasal phoretic mites is in brackets.

\begin{tabular}{lcccccr}
\hline \multicolumn{1}{c}{ Species of hummingbird } & April & May & July & August & September & Subtotal \\
\hline Amazilia saucerrottei & $0(0)$ & $9(0)$ & $35(14)$ & $0(0)$ & $0(0)$ & $44(14)$ \\
Amazilia tzacatl & $1(0)$ & $2(0)$ & $1(1)$ & $0(0)$ & $0(0)$ & $4(1)$ \\
Chalybura buffonii & $18(1)$ & $9(0)$ & $17(5)$ & $2(0)$ & $7(2)$ & $53(8)$ \\
Chlorostilbon mellisugus & $1(0)$ & $2(0)$ & $10(3)$ & $2(0)$ & $0(0)$ & $15(3)$ \\
Florisuga mellivora & $1(0)$ & $3(0)$ & $3(1)$ & $0(0)$ & $0(0)$ & $7(1)$ \\
Glaucis hirsutus & $0(0)$ & $1(0)$ & $2(2)$ & $0(0)$ & $0(0)$ & $3(2)$ \\
Phaethornis guy & $3(0)$ & $7(0)$ & $7(6)$ & $3(2)$ & $2(2)$ & $22(10)$ \\
Phaethornis striigularis & $8(0)$ & $2(0)$ & $13(2)$ & $3(2)$ & $4(3)$ & $30(7)$ \\
Total & $32(1)$ & $35(0)$ & $88(34)$ & $10(4)$ & $13(7)$ & $178(46)$ \\
\hline
\end{tabular}

Table 2. Frequency of nasal phoretic mites and mite-hummingbird species relationship collected in an Andean forest from Colombia.

\begin{tabular}{|c|c|c|c|c|c|c|c|c|c|c|c|}
\hline \multicolumn{4}{|c|}{ Phoretic nasal mite } & \multicolumn{8}{|c|}{ Mite species per hummingbird species } \\
\hline Genera & Species & Femalee & Male & As & At & $\mathrm{Cb}$ & $\mathrm{Cm}$ & $F m$ & $G h$ & $P g$ & $P s$ \\
\hline Proctolaelaps & rabulatus & 0 & 1 & & & & & & & 1 & \\
\hline \multirow[t]{5}{*}{ Rhinoseius } & caucaensis & 3 & 2 & & 1 & 2 & 1 & & 1 & & \\
\hline & luteyni & 1 & 0 & & & 1 & & & & & \\
\hline & rafinskii & 25 & 2 & 8 & & 4 & 3 & & 2 & 8 & 2 \\
\hline & richardsoni & 0 & 1 & & & & 1 & & & & \\
\hline & tiptoni & 0 & 1 & 1 & & & & & & & \\
\hline \multirow[t]{5}{*}{ Tropicoseius } & berryi & 9 & 5 & 5 & 1 & 2 & & & & 2 & 4 \\
\hline & chazdonae & 3 & 0 & 1 & & 1 & & & & 1 & \\
\hline & colwelli & 0 & 2 & 1 & & & & & & & 1 \\
\hline & erro & 6 & 0 & 1 & & 1 & 1 & & & 1 & 2 \\
\hline & uniformis & 18 & 2 & 5 & & 2 & 3 & 1 & 1 & 4 & 4 \\
\hline Total & & 65 & 16 & 22 & 2 & 13 & 9 & 1 & 4 & 17 & 13 \\
\hline
\end{tabular}

Amazilia saucerrottei (As), Amazilia tzacatl (At), Chalybura buffonii (Cb), Chlorostilbon mellisugus (Cm), Florisuga mellivora (Fm), Glaucis hirsutus (Gh), Phaethornis guy $(\mathrm{Pg})$, Phaethornis strizularis (Ps).

G. hirsutus were restricted to a subset of plots (Figure 1). Although the $R$. rafinskii, T. berryi and T. uniformis mite species were found in the majority of the plots, other mite species exhibited localized distribution (Figure 2). Sexual dimorphism among nasal mites was evident, and the females were more widely distributed across the plots than were males (Figure 2).

In total, 65 female and 16 male nasal mites were analyzed for at least nine and at most 25 chaetotaxic characteristics, resulting in their classification into three genera and eleven species. In addition, measurements were obtained for DPL, DPW and z5, the median values of which are presented in Table 4 . These morphometric characteristics were not sufficient for differentiation between species, as indicated in Figure 3. The set of morphological characters related to gnatosoma, idiosoma and chaetotaxic characteristics were fundamental to the identification of nasal mites, but the morphometric variables (DPL, DPW and z5) did not facilitate differentiation.

\section{Discussion}

Few studies provide information about the mite - hummingbird relationship. In southern Colombia, studies by Fain and Hyland (1980) and Ohmer et al. (1991) registered a total of 16 species of phoretic mites present in the nostrils of twenty species of hummingbirds. Our results for the Andean region of this country show the presence of seven mite species (P. rabulatus, $R$. luteyni, $R$. rafinskii, T. berryi, T. colwelli, T. erro and T. uniformis). These new records are of great value, as they strengthen the understanding of these mites and their relationships with birds.

Observations made by O'Connor et al. $(1991,1997)$ of $P$. guy and by Colwell (1979) of $G$. hirsutus indicate that a single bird may carry different nasal phoretic mite species. This observation was also made in the present work for $R$. rafinskii and T. uniformis, confirming that phoresis is a determining factor in the dispersion of mites.

Other studies developed by O'Connor et al. (1991) and Guerra et al. (2010) describe P. rabulatus species as exclusive flower mites of the Apocynaceae and Bromeliaceae families. Baker and Yunker (1964) previously documented T. braziliensis, T. peregrinator and T. erro mites in bromelia flowers from Brazil and Mexico and T. venezuelensis and T. heliconiae in Heliconia bracts (Venezuela and Panama) and Heliconia cuttings (Colombia). In Brazil, T. braziliensis mites were rediscovered and redescribed as Rhinoseius braziliensis based on their presence in bromeliads (FLECHTMANN; JOHNSTON, 1978). The authors of these works suggest that birds such as hummingbirds do not act as 
Table 3. Capture, reproductive and morphometric variables related to the presence of nasal phoretic mites of hummingbirds in Colombia.

\begin{tabular}{|c|c|c|}
\hline Bird Variables & Number & Presence of nasal mites $N(\%)$ \\
\hline \multicolumn{3}{|l|}{ Capture variables } \\
\hline Plot* & 178 & $46(25.8)$ \\
\hline \multicolumn{3}{|l|}{ Date** } \\
\hline April & 32 & $1(3.1)$ \\
\hline May & 35 & $0(0.0)$ \\
\hline July & 88 & $34(38.6)$ \\
\hline August & 10 & $4(40.0)$ \\
\hline September & 13 & $7(53.9)$ \\
\hline \multicolumn{3}{|l|}{ Capture } \\
\hline First capture & 124 & $35(28.2)$ \\
\hline Recapture & 54 & $11(20.4)$ \\
\hline \multicolumn{3}{|l|}{ Age } \\
\hline Immature & 8 & $3(37.5)$ \\
\hline Adult & 32 & $10(31.3)$ \\
\hline Unknown & 138 & $33(23.9)$ \\
\hline \multicolumn{3}{|l|}{ Sex } \\
\hline Female & 60 & $14(23.3)$ \\
\hline Male & 63 & $13(20.6)$ \\
\hline Unknown & 55 & $19(34.6)$ \\
\hline \multicolumn{3}{|c|}{ Reproductive variables } \\
\hline \multicolumn{3}{|c|}{ Brood patches * } \\
\hline Absent & 110 & $26(23.6)$ \\
\hline Loss of feathers & 15 & $9(60.0)$ \\
\hline Vascularized & 9 & $3(33.3)$ \\
\hline Wrinkled & 10 & $4(40.0)$ \\
\hline Moult & 1 & $0(0.0)$ \\
\hline Unknown & 33 & $4(12.1)$ \\
\hline \multicolumn{3}{|l|}{ Protuberance } \\
\hline None & 100 & $28(28.0)$ \\
\hline Small & 12 & $2(16.7)$ \\
\hline Medium & 20 & $8(40.0)$ \\
\hline Large & 13 & $4(30.8)$ \\
\hline Unknown & 33 & $4(12.1)$ \\
\hline \multicolumn{3}{|c|}{ Morphometric variables } \\
\hline Exposed culmen & 147 & $43(29.3)$ \\
\hline Total culmen & 137 & $42(30.7)$ \\
\hline Beak length & 147 & $43(29.3)$ \\
\hline Beak width & 147 & $43(29.3)$ \\
\hline Weight & 79 & $15(19.0)$ \\
\hline
\end{tabular}

carriers for mites. However, our identification of $P$. rabulatus as phoretic nasal mites of $P$. guy hummingbirds is of great value, as it contradicts the hypotheses formulated in previous studies; however, further observations to establish the true role of hummingbirds as $P$. rabulatus phorontes are needed.

Although no statistical associations were observed between variables related to morphometric aspects of the birds and the presence of mites, this study did find an association between phoresis and the reproductive variable "brood patches". The impact of phoretic mites on the reproductive development of their host birds remains unknown.

Colwell $(1973,1986)$ suggests that, under favorable weather conditions, nasal mite populations in a plantation are determined by two main factors: rapid reproduction within flowers and the ease of movement of female mites between inflorescences. In this study, the phenomenon of dispersion was evident during

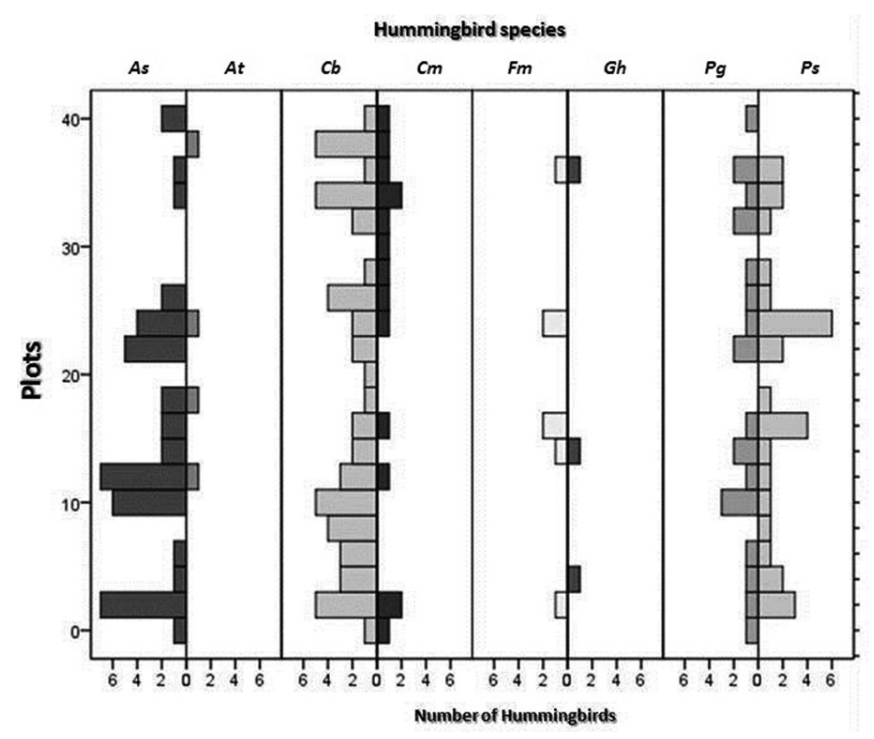

Figure 1. Spatial distribution of hummingbirds collected in a forest plantation in Colombia. Amazilia saucerrottei (As), Amazilia tzacatl (At), Chalybura buffonii (Cb), Chlorostilbon mellisugus $(\mathrm{Cm})$, Florisuga mellivora (Fm), Glaucis hirsutus (Gh), Phaethornis guy (Pg), Phaethornis striigularis (Ps).

Table 4. Mean values and standard deviation of dorsal plate length (DPL), dorsal plate width (DPW) and setae z5 long (z5) for nasal mites recovered from hummingbirds in Colombia.

\begin{tabular}{|c|c|c|c|c|c|c|c|c|c|c|c|c|}
\hline \multirow{3}{*}{$\begin{array}{l}\text { Species of } \\
\text { nasal mite }\end{array}$} & \multicolumn{6}{|c|}{ Male } & \multicolumn{6}{|c|}{ Female } \\
\hline & \multicolumn{2}{|c|}{ DPL } & \multicolumn{2}{|c|}{ DPW } & \multicolumn{2}{|c|}{$\mathrm{z5}$} & \multicolumn{2}{|c|}{ DPL } & \multicolumn{2}{|c|}{ DPW } & \multicolumn{2}{|c|}{$\mathrm{z5}$} \\
\hline & $\begin{array}{c}\text { Mean } \\
(\mu \mathrm{m})\end{array}$ & SD & $\begin{array}{c}\text { Mean } \\
(\mu \mathrm{m})\end{array}$ & SD & $\begin{array}{c}\text { Mean } \\
(\mu \mathrm{m})\end{array}$ & SD & $\begin{array}{c}\text { Mean } \\
(\mu \mathrm{m})\end{array}$ & SD & $\begin{array}{c}\text { Mean } \\
(\mu \mathrm{m})\end{array}$ & SD & $\begin{array}{c}\text { Mean } \\
(\mu \mathrm{m})\end{array}$ & SD \\
\hline Proctolaelaps rabulatus & 349.4 & & 232.2 & & & & & & & & & \\
\hline Rhinoseius caucaensis & 372.6 & 9.55 & 202.8 & 0.00 & 71.2 & 11.10 & 434.5 & 18.46 & 294.6 & 37.98 & 59.3 & 7.85 \\
\hline Rhinoseius luteyni & & & & & & & 415.0 & & 192.6 & & 67.7 & \\
\hline Rhinoseius rafinskii & 434.6 & & 322.9 & & 80.4 & & 437.7 & 45.51 & 275.8 & 55.10 & 72.1 & 17.54 \\
\hline Rhinoseius richardsoni & 371.3 & & 202.0 & & 61.4 & & & & & & & \\
\hline Rhinoseius tiptoni & 376.4 & & 194.7 & & 87.8 & & & & & & & \\
\hline Tropicoseius berryi & 387.7 & 51.07 & 262.5 & 45.51 & 57.8 & 24.30 & 455.4 & 61.47 & 315.7 & 63.64 & 62.3 & 30.31 \\
\hline Tropicoseius chazdonae & & & & & & & 425.8 & 63.33 & 268.8 & 28.57 & 49.9 & 38.61 \\
\hline Tropicoseius colwelli & 437.0 & 18.24 & 269.0 & 29.27 & & & & & & & & \\
\hline Tropicoseius erro & & & & & & & 548.2 & 157.32 & 289.7 & 42.51 & 68.1 & 30.19 \\
\hline Tropicoseius uniformis & 399.9 & 4.88 & 212.1 & 44.05 & 54.2 & & 421.7 & 33.99 & 256.8 & 52.02 & 60.1 & 20.03 \\
\hline
\end{tabular}


Phoretics nasal mites species

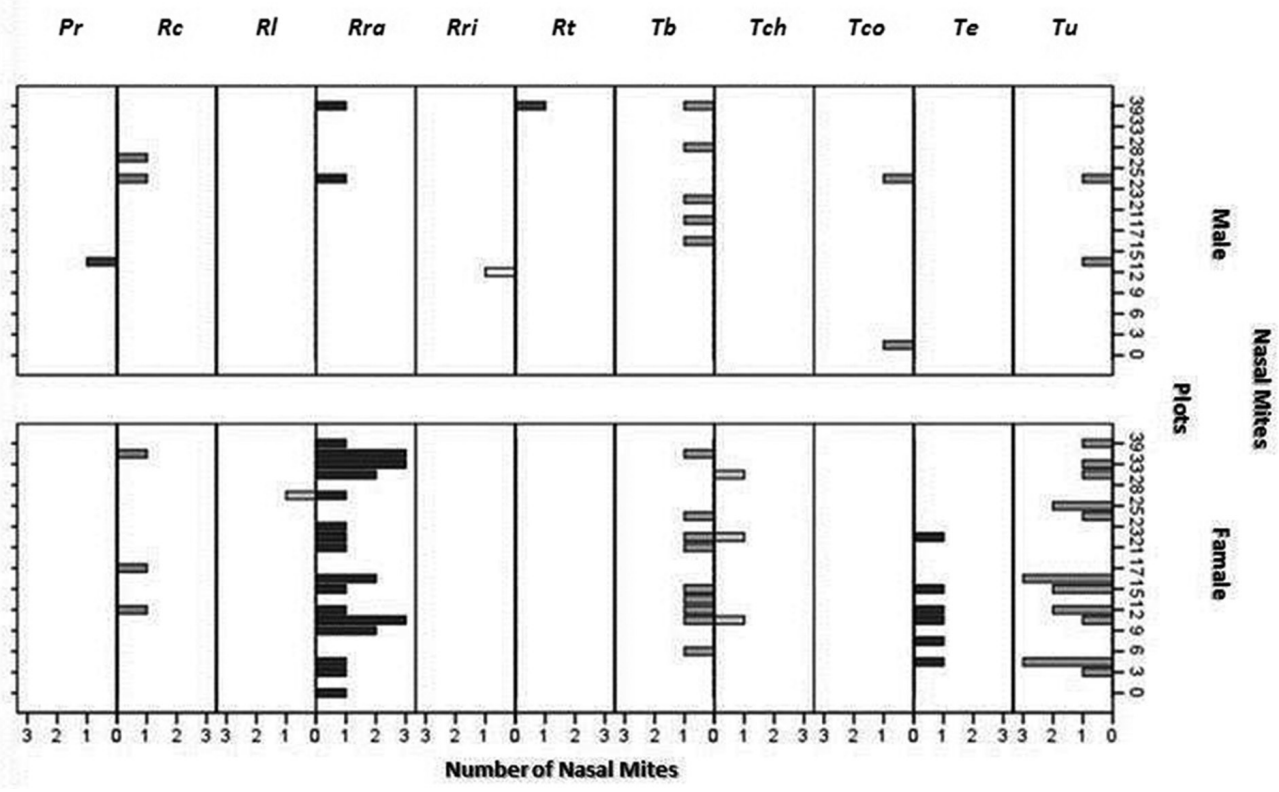

Figure 2. Nasal phoretic mite species collected in a forest plantation in Colombia. Proctolaelaps rabulatus (Pr), Rhinoseius caucaensis (Rc), Rhinoseius luteyni (Rl), Rhinoseius rafinskii (Rra), Rhinoseius richardsoni (Rri), Rhinoseius tiptoni (Rt), Tropicoseius berryi (Tb), Tropicoseius chazdonae (Tch), Tropicoseius colwelli (Tco), Tropicoseius erro (Te), Tropicoseius uniformis (Tu).
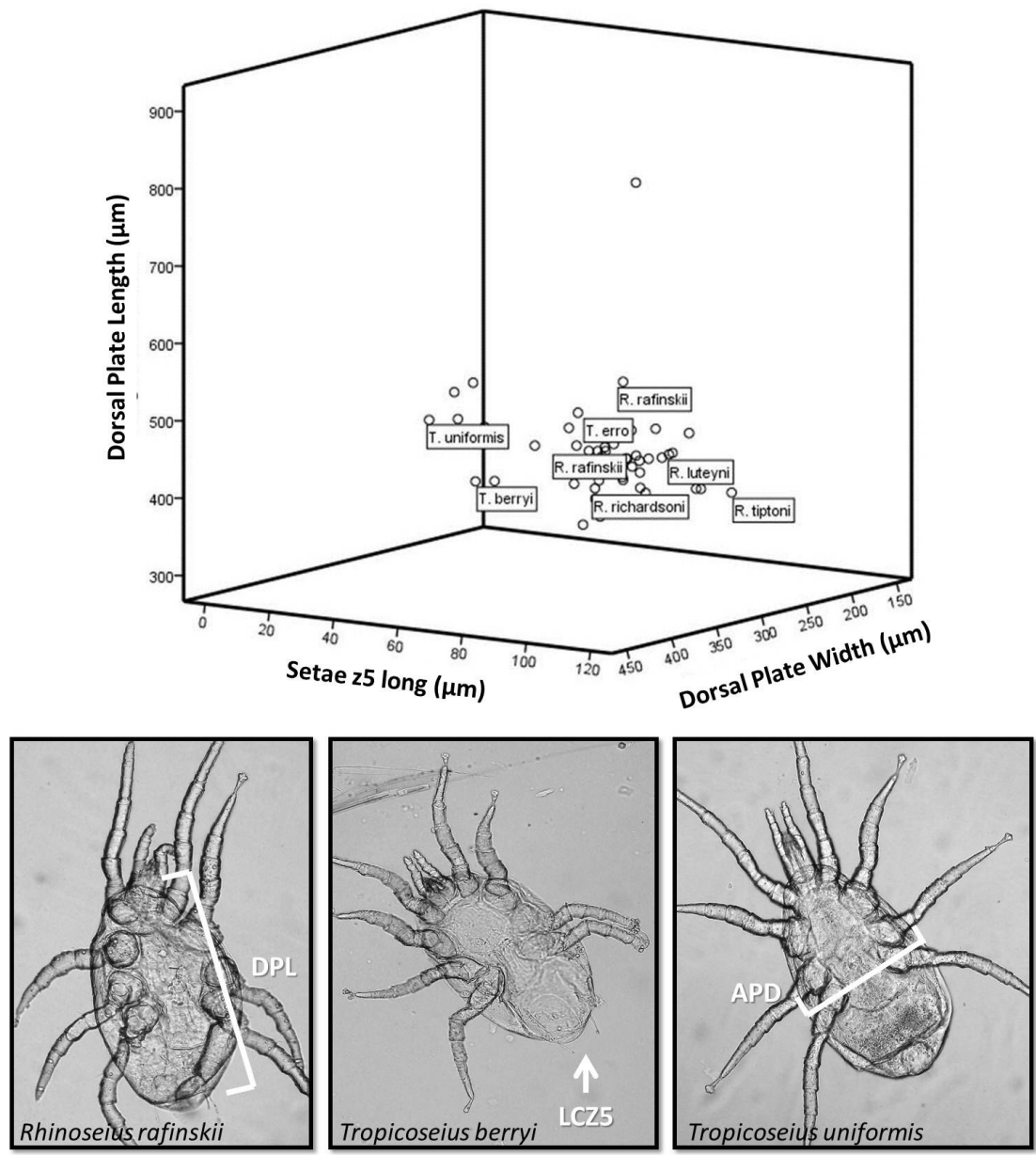

Figure 3. 3-D dispersion graphic for analyses of major components (DPL, DPW and z5) of nasal phoretic mites recovered from hummingbirds in Colombia. 
the month of July, when there was an increase in floral supply following an increase in precipitation. These are ideal conditions for an increase nasal mite, which is facilitated by dispersion via at least three of the eight species of hummingbirds (A. saucerrottei, P. guy and C. buffonii) (CASTAÑO et al., 2008).

Consistent with previous work, we identified several species of mites from a single hummingbird. Moreover, the species of birds (A. saucerrottei, P. guy and C. buffonii), their observed habitat specificity and their territorial foraging behavior are likely to have facilitated the spread of mites within the area studied. Female nasal mites were collected in the majority of the plots visited, as was demonstrated statistically.

\section{Acknowledgements}

The authors express their thanks to Dr. Robert Colwell for his suggestions and collaboration in the collection of the bibliographic material. This research was supported by the Research Group on Tropical Ecosystems and the CIENVET group of the University of Caldas and by the sponsorship of the Central Hydroelectric of Caldas S.A. E.S.P.

\section{References}

Baker EW, Yunker CE. New Blattisociid mites (Acarina: Mesostigmata) recovered from neotropical flowers and hummingbirds' nares. Ann Entomol Soc Am 1964; 57(1): 103-126.

Castaño Villa GJ, Morales Betancourt BJA, Bedoya-Álvarez AML. Aportes de una plantación florestal mixta a la conservación de la avifauna en el Cañón del río Cauca, Colombia. Rev Fac Nac Agron Medellin 2008; 61(1): 4358-4365.

Colwell RK. Competition and coexistence in a simple tropical community. Amer Nat 1973; 107(958): 737-760. http://dx.doi. org/10.1086/282872

Colwell RK. The geographical ecology of hummingbird flower mites in relation to their host plants and carriers. In: Rodríguez JG. Recents Advances in Acaralogy. New York: Academic Press; 1979. p. 461-468.

Colwell RK. Population structure and sexual selection for host fidelity in the speciation of hummingbird flower mites. In: Karlin S, Nevo E. Evolutionary processes and theory. New York: Academic Press; 1986. p. $475-495$.

Colwell RK. Effects of nectar consumption by the hummingbird flower mite Proctolealaps Proctolaelaps kirmsei on nectar availability in Hamelia patens. Biotropica 1995; 27(2): 206-217. http://dx.doi. org/10.2307/2388996

Colwell RK, Naeem S. The first known species of hummingbird flower mite North of Mexico: Rhinoseius epoecus n. sp. (Mesostigmata: Ascidae). Ann Entomol Soc Am 1979; 72(4): 485-491.

Dusbäbek F, Černý V. The nasal mites of Cuban birds. I. Ascidae, Ereynetidae, Trombiculidae (Acarina). Acarologia 1970; 12(2): 269-281. PMid:5530497.

Dusbäbek F, Literak I, Capek M, Havlicek M. Ascid mites (Acari: Mesostigmata: Ascidae) from Costa Rican hummingbirds (Aves: Trochilidae), with description of three new species and a key to the Proctolaelaps belemensis species group. Zootaxa 2007; 1484: 51-67.
Fain A, Hyland KE. New species of the genus Rhinoseius Baker and Yunker, 1964 (Mesostigmata: Ascidae) phoretic on Colombian hummingbirds. Int J Acarol 1980; 6(1): 15-24. http://dx.doi. org/10.1080/01647958008683187

Fain A, Hyland KE, Aitken THG. Nouveaux acariens Ascidae (Mesostigmates) phorétiques dans les fosses nasales de colibris (Note préliminaire). Bull Annls Soc R Belge Ent 1977; 113: 184-186.

Flechtmann CHW, Johnston DE. Rediscovery and redescription of Rhinoseius braziliensis (Acari: Ascidae). Rev Bras Entomol 1978; 22(3-4): 165-166.

Guerra TJ, Romero GQ, Costa JC, Lofego AC, Benson WW. Phoretic dispersal on bumblebees by bromeliad flower mites (Mesostigmata, Melicharidae). Insect Soc 2010; 59(1): 11-16. http://dx.doi.org/10.1007/ s00040-010-0091-4

Henderson RC. Technique for positional slide-mounting of Acari. SAASP 2001; 7: 1-4.

Heyneman AJ, Colwell RK, Naeem S, Dobkin DS, Hallet B. Host plant discrimination: Experiments with hummingbird flower mites. In: Price PW, Lewinsohn TM, Fernandes GW, Benson WW. Plant-Animal Interactions: Evolutionary ecology in tropical and temperate regions. New York: John Wiley \& Sons; 1991. p. 455-485.

Hoffmann A. Animales desconocidos: Relatos acarológicos. México: Fondo de la Cultura Económica; 1996.

Hunter PE. New Rhinoseius species (Mesostigmata: Ascidae) from Costa Rican hummingbirds. J GA Entomol Soc 1972; 7(1): 26-35.

Hyland KE, Fain A, Moorhouse AS. Ascidae associated with the nasal cavities of Mexican birds (Acarina: Mesostigmata). J New York Entomol Soc 1978; 86(3): 260-267.

Lara C, Ornelas JF. Nectar "theft" by hummingbird flower mites and its consequences for seed set in Moussonia deppeana. Funct Ecol 2001; 15(11): 78-84.

MacChioni F. Importance of phoresy in the transmission of Acarina. Parassitologia 2007; 49(1-2): 17-22. PMid:18412039.

Micherdzinski W, Lukoschus FS. Rhinoseius rafinskii, a new species from Ecuador and Venezuela (Acari, Gamasina, Ascidae). Zool Meded 1980; 55(6): 65-79.

Naskrecki P, Colwell RK. Systematics and host plant affiliations of hummingbird flower mites of the Genera Tropicoseius Bayer and Yunker and Rhinoseius Baker and Yunker (Acari: Mesostigmata: Ascidae). Maryland: Entomological Society of America, 1998.

O'Connor BM, Colwell RK, Naeem S. Flower mites of Trinidad II. The genus Proctolaelaps (Acari: Ascidae). West $N \mathrm{Am}$ Naturalist 1991; 51(4): 348-376.

O'Connor BM, Colwell RK, Naeem S. The flower mites of Trinidad III. The genus Rhinoseius (Acari: Ascidae). Misc Publ Mus Zool, Univ Mich 1997; 184: 1-32.

Ohmer C, Fain A, Schuchmann KL. New ascid mites of the genera Rhinoseius Baker and Yunker, 1964, and Lasioseius Berlese, 1923 (Acari: Gamasida: Ascidae) associated with hummingbirds or hummingbird-pollinated flowers in Southwestern Colombia. J Nat Hist 1991; 25(2): 481-497. http://dx.doi.org/10.1080/00222939100770301

Proctor H, Owens I. Mites and birds: diversity parasitism and coevolution. Trends Ecol Evol 2000; 15(9): 358-364. http://dx.doi. org/10.1016/S0169-5347(00)01924-8 
Ralph CJ, Geupel GR, Pyle P, Martin TE, Desante DF, Milá B. Manual de métodos de campo para el monitoreo de aves terrestres. Albany: Pacific Southwest Research Station, Forest Service, U.S. Department of Agriculture; 1996. 46 p. Gen Tech Rep PSW-GTR-159.

Remsen JV Jr, Cadena CD, Jaramillo A, Nores M, Pacheco JF, Robbins $\mathrm{MB}$, et al. A classification of the bird species of South America. American Ornithologists' Union Homepage [online] 2013 [cited 2013 Jan 16]. Available from: http://www.museum.lsu.edu/ Remsen/SACCBaseline. html.
Silva M, Vásquez C, Fuentes LD, Díaz L, Lorbes J, Malvacias M. Variación intraespecífica de ácaros laelápidos asociados a Holochilus sciureus (Rodentia: Cricetidae) en el estado Portuguesa, Venezuela. Bol Centro Invest Biol 2009; 43(3): 309-323.

Velásquez T, Ornelas JF. Pollen consumption by flower mites in three hummingbird-pollinated plant species. Exp Appl Acarol2010; 50(2): 97-105. PMid:19763848. http://dx.doi.org/10.1007/ s10493-009-9309-4 